\title{
Pre-gradual preparation of future teachers for cooperation and communication with student's parents
}

\section{Frýdková, Eva ${ }^{a}$}

${ }^{a}$ Department of Pedagogy, University SS. Cyril and Methodius in Trnava, Slovakia.

\begin{abstract}
Partnership of family and school is the subject of interest not only to the non-professional public, but also to profesionals of pedagogical, sociological and psychological. The reasons are continuous efforts to improve education of children and transformation of schools to modern institutions, which cooperate with their surrounding areas providing quality services to their attendingstudents and their parents. Partnership of school and family of student is organical part of these efforts and it becomes the important part of evaluation of school's quality.

Cooperation of family and school is an undividible part of the teachingprofession. At the same time it belongs to areas which cause the biggest problemsto graduates in pedagogical practise. This observation is not only drawn from researche in this area, but also from interviews which were conducted with students after attending pedagogical practise seminars in undergraduate studies. The text is focused on undergraduate preparation of future teachers for work with parents. It shows if they are theoretically and practically ready and it is foccussed on the possibilities of evolving practical skills and applications of theoretical knowledge from the subject's area.
\end{abstract}

Keywords: pre-gradual preparation; pedagogical practise; cooperation; teacher; parent. 


\section{Introduction}

In the last decades we have been witnesses of economincal, cultural, political, ideological and other changes of society, which have been reflected also in nowadays characteristics and features of family and school. Within his or her practise, a teacher meets with various types of families and parents with who he or she has to cooperate and communicate. In practise they are still more often in touch with patch-work families, families created by people of the same sex, with people who are challenged by a sociocultural handicap and others, which require individual access. It goes without doubt that these changes and characteristics of families are reflected also in connection and communication of a teacher with student parents. In this day and age, relationship of family and school is not influenced only by the type of family, but also by other determinants coming from family and school area. On the side of family, there are mainly social-economical conditions, on the side of teacher it is the length of pedagogical experience.

\section{Pre-gradual preparation of future teachers}

Pre-gradual preparation of teachers forms an important part of their profesional development, it creates the base for future professionality. Kasáčová (2006: 27) in this connection mentions that ,pregradual preparation as basic time has to create an integral part of the system of teacher education on the base of respecting the rule that professional is not preparing for profession only one time and forever and definitively". This should fulfill the conditions and requirements in order to ensure a good start, and to provide a wide base of specific knowledge and skills or abilities. Preparing education in theoretical and practical level forms the base of professional teacher competencies. Slávik and Gáborová (2007) emphasize the necessity of moving the preparation of future teachers in university-based teacher-training from monological presentation of teaching materials to partner dialogues and to discussion in the interest of mutual foundation and achieving the results in an atmosphere of mutual acceptance, emphaty and authenticity. According to authors, an caring and emphatic teacher in the long run supplies knowledge but at the same time also caters for the personal needs of students which enhances a positive relationship with each other undoubtedly and also to the subject taught. By this approach, teachers get wider feedback about the teaching process which enables him or her correct and adapt not only the attitude between teacher and students to the extent of becoming a role model or idol. This helps students and learners to form a positive model of their future (acceptable and emphatical) behaviour towards students but also to student's parents. One important condition is the authenticity of the teacher's behaviour. Frequently mentioned requiremets are the bases of profesional forming part of which is student's getting know all the aspects of teacher's work. Kosová (2006: 17) 
states that the biggest obstacles in development of profesionality are in college's education or teaching following:

- Ignorance towards theories of teaching and processes in relation to teaching of university student from the side of universities teachers.

- Lack of acceptance towards the fact that becoming a teacher is a step-bystep process with distinct, consecutive phases of.

- Excessive useof knowledge-receptional methods of teaching (teacher's speech), its inefficiency for the process of teaching and oppositness of profesional focus of study.

- Teaching of methodological and pedagogical subjects by teachers without sufficient practical experience, resulting in failure to meet the requirements of supervising students' practise.

- Non-adequate evaluation of pedagogical students, pointless testing by knowledge-based exams instead of evaluation of profesional competencies of teachers including state exams.

Professionality of teachers according to Kasáčová (2006) includes a personal, ethical and specific dimension. By reaching and meeting these dimensions study programmescan develop the teacher's professionality, which depends on small but continuous steps, moving forward in practical teacher's performance and also develops a system of life-long-learning for teachers.

Teacher's education constitutes itself by four basic areas:

- General base,

- pedagogical-psychological element or part

- specific-subject part,

- $\quad$ pedagogical practice (Mendelová, 2011).

Theoretical preparation should not be focused only on summarizing knowledge and information. Istead, focus should be mainly on evaluation, analysis, comparison and integration to practice and also to other areas. Students should be made aware that the main point of their training is not speeches and seminars but mainly their own studies. According to Šimoník (2008), pedagogical-psychological preparation has its own internal structure and processual back-up. Pedagogical and psychological subjects are outlined according to individual science disciplines (general pedagogy, general psychology etc.) and it is possible that they are more tracted on the general level as on the school level which is closer to teaching practice. Submitted theory is very general and student is not able to applicate it.

Application of acquired theoretical knowledge which enables to students to put this knowledge into pedagogical practice should constitute an undividable part of their 
pre-gradual preparation. Pedagogical practice enables students not only to interconnect theory with practice but also to form their own personal competencies and to develop skills necessary for performing their profession. Sirotová (2015) considers pedagogical practice as certain form of experience and professional teaching which creates the base for development of teacher's style.

\subsection{Pedagogical practice of future teachers}

The area of cooperation of family and school plays a specific role from the pedagogical practice point of view. In contrast to the fact that it is among the most difficult parts of the teacher profession, this area is often underestimated by both, students as well as future teachers and most often for this reason they are not utilizing the possibilities of pedagogical practice to communicate with parents, parent-teacher-meetings or to conduct interviews with instructing teachers on the frequent problems with parents and on their experience on barriers in mutual cooperation. By creating an interest of students, future teachers in this area of education the amount of "reality shock", which is pointed out by more authors (Kurincová, 2001; Kasáčová, 2007, Šimoník, 2006).

From the point of view of preparation of future teachers for work with student's parents by way of individual subjects of pedagogical- psychological base of study they are gradually getting familiar with characteristics of family area, its diagnostic, with communication techniques. Moreover, prospecive teachers can estimate what is possible to be used in interviews with parents, with possibilities of solutions of conflicts and so on, but often they do not put these studies to practice. At the time of entering of absolvents into a study programme to become a teacherto practice, instructors are sometimes confronted with criticism of their practical preparation while attending the study programm either by the faculty which or by older colleagues. But we do not agree with the statement ,that a beginning teacher does not know", but very often it comes to the phrase that a ,beginning teacher is not able to or can't ", which is possible to accept as criticism on practical preparation of future teachers." (Šimoník, 2008). Cooperation of family and school is the part of this criticism. The lacks are reflected for example in a insufficient response to certain emergency situations, in helplessness in organizing and offering activities, and in a severely underdeveloped ability to apply theory to school practice. We consider it a fact that after their entering into daily practice, beginning teachers have enormous problems to start any form of communication with parents of their students and also to building a bridge of information, advice and recommendations related to the education of students. Moreover, a vast number of young teachers also severely lack problem solving skills, which could help to overcome the aforementioned shortcomings in parent-teacher-communication. 
But not every university or college can prepare professional teaching skills. Šimoník (2006: 19) presents an idea that the sequence at application of knowledge (and step by step making or creating of skills) should have following degrees or grades:

1. students are introduced to new theoretical knowledge and up-to-date example of possible usage of thisknowledge in school practice. ( student is "passive" recipient of information about possibility of application.)

2. students are asked to suggest possibilities of application of new theoretical knowledge, try to evaluate usage of knowledge for pedagogical activity as to for what and how the informations can be used (Students should develop and research possibilities of application of new knowledge on a general level, not only related to parent-teacher-comunication.)

3. students should theoretically solve certain pedagogical cases which are presented to them by text, video etc. (Students develop a solution of possibility of application of new knowledge in a specific situation.)

4. students should use new knowledge in partial simulation (inscenated) situation on the faculty- "playing a role", "pedagogical studies", "performing" of part of lesson- student should explain new units, he or she should conduct an experiment etc. and other students act in student's roles, in parent's role, in roles of colleagues, etc. This should also include a "break" ( student should act practically - speak - also about the fact that it is simulated situation.)

Furthermore, the author mentions a $5^{\text {th }}$ and $6^{\text {th }}$ point, which are both connected to the teaching process and the communication with teachers under real-life conditions, that is as found in a typical school. With regard to our problem, we consider the previous four degrees as suffiicient because they show ways of preparing future teachers and creating skills which makes sense also regarding their preparation for work with parents.

Further interesting suggestions for making professional beginnings of absolvents easier in area of cooperation with family of student are also presented by Střelec (2006: 144145). This author recommens the creation of video records for training on educational activities of class teachers. Example to be analyzed include records of real and simulated class lessons, meetings of class teacher with student's parents, individual interviews of class teacher with parents and their parents, simulated performances of students before their potencial students etc. The author also suggests the use of scientific resources, which enables a non-traditional view at problems of cooperation of family and school.

Another aspect to be added is the problem of homeworks in grammer schools which was edited in the past by Maňák (1992) and which offers a blend of practical stimuli for class teachers also in connection to join student's parents. Useful are also the suggestions to students for interviews with class teachers or with student parents about cooperation with the class teacher. It is safe to say that this can develop into a fruitful active cooperation with teachers achieving their pedagogical masters degree. Communication with teachers 
from school practice, their invitation of students for speeches, where they can present their approaches, techniques and skills will undoubtedly enable students to be detect pedagogical problems and reality of nowadays school also in the area of family and school.

\section{Conclusion}

The ability to communicate with parents and to make a relationship with them belongs to the most difficult in teacher's profession. This area is more complicated when only nonsufficient pre-gradual preparation of students in the pedagogical field of study is provided before graduates enter the real-life teaching profession. During the time of the child's attendance in school, the teacher is to be consideres " a member of family" co-responsible or mutually responsible for the child's education, and that is why cooperation between family and school is of vital importance. It has been ascribed a enormous relevance mainly in the last years ( thanks to trade mechanism)because it influences also quality and fruitfullness of school.

Problems of cooperation of teachers with student parents are not new in the area of nonprofessional and professional public. The other way around, there are still discussions about the ways of communication, possibilities of mutual communication, barriers, which often stand in the way of initiating and developing a relationship or partnership between both institutions and not as the last point also about pre-graduate preparation of future teachers for this area. Methodical directions of some faculties concerning the implementation of pedagogical practice, also tutors make a point that future teachers should focus on this area during their realization of pedagogical practice. It is a sad reality that for reasons of disinterest, underestimation or fear to name only a few, communication and cooperation with student parents is bluntly ignored. From this point of view we consider it as necessary to focus our attention not only on active cooperation and communication with training teachers and other teachers, but also on creating practical skills within pre-gradual preparation of future teachers.

\section{References}

Kasačová, B. (2007). Dimenzie učitel'skej profesie. In. Profesijný rozvoj učitel'a. Prešov: Rokus. s. 19-33.

Kosová, B. (2006). Profesia a profesionalita učitel’a v teoretických súvislostiach. In. Profesijný rozvoj učitel'a. Prešov: Rokus, 7-18.

Kurincová, V. (2001). Kooperácia rodiny a školy. In. Porubská, G., Seidler, P., Kurincová, V. Diferenciácia, integrácia, kooperácia v edukačnom prostredí. Nitra: UKF.

Maňák, J. (1992). Problematika domácích úkolů na základní škole. Brno: MU. s. 157. 
Mendelová, E. (2011). Miesto pedagogickej praxe v pregraduálnej príprave učitel’ov. In. Vybrané otázky z didaktiky pedagogiky a sociálnej pedagogiky. Nitra: UKF, 359- 372.

Sirotová, M. (2015). Pedagogická prax v pregraduálnej príprave učitel'ov. Trnava: UCM.

Slávik, M. - Gáborová, L. (2007). Profesionálny aj osobnostný rozvoj učitel’ov v ich pregraduálnej aj postgraduálnej príprave. In. Ako sa učitelia učia? Zborník referátov z medzinárodnej konferencie: Prešov: FHPV, 242-244.

Střelec, S. (2006). Souvislá pedagogická praxe jako prŕležitost pro přípravu studentů na výchovné činnosti trrídního učitele. In. Filová, H. - Havel, J. Otázky hodnocení studenů na souvislých pedagogických praxích. Brno: MSD, 143-145.

Šimoník, O. (2006). Pedagogická praxe v kontextu pregraduální přípravy. In. Šimoník, O. - Havel, J. Kooperujicí učitel. Brno: MSD, 7-26.

Šimoník, O. (2008). Pedagogická praxe v prípravě budoucích učitelů. In. Havel, J. Šimoník, O. - Št’áva, J. (Eds.) Pedagogické praxe a oborové didaktiky. Zborník z medzinárodného seminára. Brno: MSD, 19 - 25. 